\title{
中国早期参加国际地质大会史事钩沉 论科学话语与国族身份的关系
}

\author{
王岫庐 \\ (中山大学,广州 510275)
}

\begin{abstract}
摘 要 国际地质大会是 19 世纪末欧洲地质学家组织成立的世界地质工 作者会议, 也是国际地质学界规模最大、影响最广的学术盛会。1906 年9月在 墨西哥首都墨西哥城举办第 10 届国际地质大会时, 中国就曾拟派员参会。此 后, 1910 年 8 月在瑞典斯德哥尔摩举办的第 11 届国际地质大会、1913 年 8 月在 加拿大多伦多举办的第 12 届国际地质大会, 中国均有正式代表出席。目前学界 对中国参与国际地质大会的早期历史关注甚少, 与会代表也都湮没无闻。本文 钩沉相关史料, 对上述史事进行梳理与考释, 从一个侧面考察 20 世纪初期中国 地质学在外患内忧的时代背景下发展起来的历史, 并进一步反思中国近代地质 学话语权力与国族身份建构之间的关联。
\end{abstract}

关键词 国际地质大会 话语权力 国族身份

中图分类号 N09

文献标识码 A 文章编号１000-0224(2020)01-0098-13

国际地质大会 (International Geological Congress, 简称 IGC, 旧译为万国地学会), 是 19 世纪末欧洲地质学家组织成立的世界地质工作者会议。1 878 年, 法国召开国际博览会期 间,第 1 届国际地质会议在巴黎召开。在距今百余年的历史中,除因两次世界大战停会之 外, 国际地质大会基本保持四年一次 (早期三年一次) 的传统, 是国际地质学界规模最大、 影响最广的学术盛会。

根据目前中国地质学史相关资料的记载, 中国参加国际地质大会始于 1906 年, 是年 2 月, 中国政府应邀参加在墨西哥首都墨西哥城召开的第 10 届国际地质大会, 由驻墨西 哥参赞梁询就近赴会; 1910 年 8 月在瑞典首都斯德哥尔摩召开第 11 届国际地质大会, 清 政府委派驻柏林公使馆外交官 Djin Da Min 参加; 1913 年 8 月在加拿大多伦多召开第 12 届国际地质大会, 我国委派广州矿业工程师 Parkin Wong 参加( [ 1 ], 195 196 页; [2], 236 页; [3],79 页)。由于中国人在这几次大会上均没有发表论文,学界一般并不重视,

收稿日期: 2019-05-31; 修回日期：2019-06-29

作者简介: 王岫庐,1978 年生,江苏扬州人,副教授, 主要研究方向为翻译学与现代中国文学研究。

基金项目：广东省哲学社会科学规划项目 “广府文化关键词英译传播影响研究” (项目编号:GD17CWW05); 高 校基本科研业务费中山大学青年教师重点培育项目 “多维视角下文学翻译批评体系的理论建构与实践研究” 
与会中国代表 Djin Da Min、Parkin Wong 等人的身份无人考证,其他参会人员也几乎完全 湮没无闻。丁文江曾指出, “前十二届大会均无中国地质学者出席会议,更不用说提交论 文”。 ${ }^{[4]}$ 有学者认为, 中国专业地质学者首次出席国际地质大会, 是 1922 年在比利时首都 布鲁塞尔召开的第 13 届国际地质大会, 当时 “翁文影作为中国地质学家代表,也是唯一 的中国代表首次出席大会”。 ${ }^{[5]}$ 实际上, 中国早期出席国际地质大会的代表,并非完全没 有受过地质学训练, 其中甚至不乏相当专业的地质学者。他们参与国际地质大会的史事, 可以从一个侧面帮助我们更加深刻地了解中国地质学在 20 世纪初期外患内忧的时代背 景下发展起来的艰难进程。为此,本文钩沉相关史料,通过对中国与会代表身份及参会情 形的考释, 对中国参与国际地质大会的早期历史略作梳理, 并进一步反思中国近代地质学 话语权力与国族身份建构之间的关联。

\section{1 中国拟派员参加第 10 届国际地质大会始末}

1906 年 9 月,墨西哥首都墨西哥城举办第 10 届国际地质大会, 会议主要议题包括不 同地质时代的气候状况、地质构造过程和火山喷发、金属矿床的成因、岩石的分类和命名 及石油问题等。中国地质史学界论及这次大会, 大多提到中国驻墨西哥使馆参赞梁询 （1870 1955) 曾代表中国出席在墨西哥举行的第 10 届国际地质学大会，“是为中国第一 次派代表出席国际地质大会”。[6]

根据清廷档案记载,光绪三十年十二月十六日 (1905 年 1 月 21 日 ), 中国驻美、秘、 古、墨公使梁诚(1861 1917) 在呈给外务部的咨文中提及“第十期万国地学会”。( [1], 196 页) 光绪三十一年正月二十三日 (1905 年 2 月 26 日), 外务部就此事致墨西哥驻华代 使照会。 ${ }^{[7]}$ 同年十月二十六日 (1905 年 11 月 22 日), 墨西哥驻华署使致庆亲王奕臥照会, 正式邀请清政府参会: “第十期万国地学会, 能于西历一千九百零六年九月间开办, 因议 会之事,最关紧要,本政府甚愿此会得最大成效,本大臣兹奉本政府之谕,特请贵国政府委 派官员,或一员,或几员人会”, ${ }^{[8]}$ 并随函附上第十期万国地学会组委会的成员名单和简 要议程。因此,清政府应大致了解会议主题和性质。光绪三十一年十一月初二(1905 年 11 月 28 日), 外务部致梁诚的咨文中言及“所有各国地学博士皆可人会, 以便互相讨论地 质等。语是该会博采與图, 辨别土宜, 于环球地理之学,籍资考证, 良有禆益, 相应咨行”, 要求梁诚 “就近遴派妥员, 届时人会” ${ }^{[9]}$, 更可见对于万国地学会的学术性质, 清政府是知 晓的。与西方相比,近代中国地质学发展起步较晚, 尚没有中国自己的“地学博士”, 且墨 西哥位置遥远, 出于就近派员的考虑, 梁诚于光绪三十一年十二月十六日 (1906 年 1 月 20 日)致外务部咨呈称“此查有驻墨二等参赞兼总领事浙江补用道梁询,堪以派令,届期就 近赴会”,并附注梁询中西文衔名: “驻墨参赞兼总领事梁询, Liang Hsün, Chargé d'Affaires ad interim and Consul-General at City of Mexico”。外务部于光绪三十二年二月二十九日 (1906 年 3 月 23 日) 承准梁询赴会。 ${ }^{[10}$

1906 年, 中国第一次派代表出席国际地质大会, 从邀请参会到遴选代表, 官方照会咨 文往来不下数十次, 是一次相当正式的外交事件。事实上, 中国此次参会, 与当时中墨两 国外交关系的发展有很大关系。1899 年, 中墨两国签订通商条约之后, 两国商业往来及 
华工应招去墨人数增多。1903 年, 中国驻美国、秘鲁、墨西哥、古巴公使梁诚奏请清政府 在墨西哥设置领事馆,保护当地侨民。清廷命梁诚兼领墨西哥使馆, 原先所兼驻西班牙使 臣一职由驻法使臣兼领。1904 年, 梁诚赴墨西哥城呈递国书, 开办使署分馆, 同时设总领 事兼参赞一员。是年,墨西哥亦派员充驻广州等处领事官。 ${ }^{[11]}$ 根据 1905 年墨西哥《外交 部官方公报》记载, 中国驻墨西哥使馆第一任工作人员包括中国公使梁诚、参赞兼总领事 梁询、外国秘书 Clarence Key, 以及一位名为 Fong Yin-Kai 的中方随员。 ${ }^{[12]}$ 美国国会有关 于此事的文献记录,并评论“这是中国第一次感到与墨西哥的国家事务或商业利益足够 重要,需要驻墨西哥的外交使馆代表的保护。”[13]

中墨两国互设领事后,官方交往更为频繁,1905 年墨西哥总统公选连任,向清政府呈 递国书, “是年, 墨开万国地理会, 请中国派员人会, 许之。” ${ }^{[14]}$ 作为在墨西哥设立使馆不 久的中国,派出代表参会更多是出于外交礼节而非学术交流的考虑, 这便是清政府派员参 加第十期万国地学会的背景。最终, 梁询其实并未最终真正出席此次会议。据大会统计, 会议注册人数为 707 人, 实际参加人数为 321 人, 中国代表团注册人数一人, 并未到 场。 ${ }^{[15]}$ 梁询收到清政府的派令后注册参会, 但最终是由于事务繁忙无暇出席, 还是发觉此 次会议实属学术而非外交场合而决定无需到场, 暂无从得知。但近代中国开始参与国际 学术交流过程中的不适应,从中或可窥见端倪。就此次地质大会而言,墨西哥驻华署使呈 递给庆亲王的信函原文为西班牙文,特请清政府派“delegados” (即“代表”) 出席,而中文 译员呈递给庆亲王奕㤼的照会, “delegados”一词翻译为“官员”, 从一个侧面反映了当时 清政府对外交往的惯例, 只能由 “官员” 作为中国代表出席国际场合。但是这种仪式性的 “代表”,在学术场合难免显得困宕。

\section{2 瑞典第 11 届国际地质大会上的中国代表}

1910 年 8 月,在瑞典斯德哥尔摩举办的第 11 届国际地质大会上, 中国派出留德学生 金大敏参会。宣统二年四月十九日 (1910 年 5 月 27 日), 瑞典驻华公使致函清政府外务 部, 表示已经知悉并转告瑞典政府, 中国委任在德国柏林的留学生 Djin Da Min 作为“中国 委员” (Chinese delegate) 参加本年八月在瑞典举办的 “万国地理会”。中国译员翻译此函 时,将 Djin Da Min 这个名字根据拼音, 误译为“金大明”。 ${ }^{[16]}$ Djin Da Min 的确前往斯德哥 尔摩参会, 因为在 1912 年出版的大会议程及报告汇总里, 列出了中国参会代表名单: “DJIN DA MIN,Délégué du Gouvernement impérial de la Chine”。( [17],33 页)并且, 作为 中国的官方代表,他还担任了大会主席团的副主席。( [ 17],80 页)但是他没有向大会提 交论文,会议的其他活动、考察、评论中也不曾出现他的名字。长期以来, 由于缺乏史料考 证, 国内外学界对“Djin Da Min” 的身份所知甚少, 在研究中也大多采用 Djin Da Min 拼音 注名。 ${ }^{[18]}$ 沈德容 (Grace Yen Shen) 认为, Djin Da Min 作为清朝特使出席第 11 届国际地质 大会, 名义上与世界上最有成就、最有名望的地质学家一同担任了大会副主席, 其实这只 不过体现了清政府看重形式，“通过出席而非通过专业知识来代表中国” 的惯例。 246 页) 事实上,Djin Da Min 即中国留德学生金大敏, 毕业于德国柏林大学哲学院矿物学 
府赴会相比,已经是更为合理可行的做法。

金大敏是清政府总理衙门 1896 年首批派送 16 名赴欧留学的同文馆学生之一。这批 学生中有 4 名前往德国的公费生, 金大敏便是其中一员。( [20],74 页) 当时公费留欧学 生一般以 3 年为期,第一期学习期满后,金大敏于 1889 年 10 月至 1906 年 7 月期间继续 在柏林大学学习矿山矿物学 (Bergforschung)。首批同文馆赴欧学生的就学、生活、经费等 等, 由总理衙门交待各驻外使馆办理。部分学生直接进人大学, 大多数先在中学或师范学 校就读一、二年后, 再由使馆交涉安排进人大学。这些留学生除了自行负担伙食费及零用 钱之外, 其学费、书籍费、文具费, 以及来回交通费用都由使馆支付, 平时也居住于使馆内, “三年期满由出使大臣奏保升阶”。 ${ }^{[21]}$ 由此可见,金大敏当时应该与中国驻德使馆关系密 切。根据中国第一历史档案馆藏档案“出使德国大臣荫昌奏为同文馆学生金大敏等赴德 学习期满请奖事折”,1905 年荫昌 (1859 1934) 为出使德国大臣, 曾专门为金大敏赴德学 习期满请奖,称“同文馆学生金大敏, 自光绪二十二年九月十九日到德起, 连闰扣至三十 一年六月十八日,已届第三次三年期满”, “金大敏第一次期满后, 送人矿务学堂学习矿 务, 潜心研究, 在学堂功课大考已毕后, 仍愿留德—、二年, 游历各矿厂、矿山以资考验”, 并称其“考试均堪人格,洵属者有成效,且不染外洋习气，志尤可嘉”, 因而 “俯准将四品衔 候选主事金大敏免选主事, 以员外郎分部遇缺即补,并赏换三品顶戴理事同知衔,候选笔 帖式”。([20],76 页) 根据京师同文馆章程, 三年一大考, 考试优秀者授七、八、九品衔, 七品再考取一等的授为主事, 成绩优异者则由总理衙门奏保官职, 自八、九品衔起至分部 行走。 ${ }^{[22]}$ 从荫昌奏折中, 可以推断金大敏在京师同文馆已有官衔, 后在德国读书期间,亦 颇受中国驻德使馆重视, 不断被出使大臣“奏保升阶”以至官至三品。

根据柏林皇家弗里德里希威廉大学 (Königlichen Friedrich-Wilhelms-Universität zu Berlin) 的年鉴记录, 金大敏曾于 1903 1904 年冬季学期担任过该校中文讲师的教职, ${ }^{[23]}$ 这 可能和他在同文馆担任翻译、在语言方面比较有天分有关。至于他在矿物专业方面的学 习情况, 目前我们所知甚少。若金大敏确实如荫昌奏折中所言, 在 “矿务学堂学习矿务, 潜心研究”, 1906 年从柏林大学毕业后, 又继续留德 “游历各矿厂、矿山以资考验”, 那么 1910 年派他代表中国前往斯德哥尔摩出席第 11 届国际地质大会, 确实是一个合适的安 排。尤其此次大会主题之一为 “世界铁矿石资源” ${ }^{[24]}$, 金大敏在这方面接受过系统专业 的训练。但从荫昌奏请为金大敏 “赏换三品顶戴理事同知衔, 候选笔帖式” 的官衔中, 又 可推断金大敏留德期间,更有可能主要从事使馆文书工作,而非实质性的地质科考。在一 定程度上,这也解释了金大敏代表中国参加第 11 届国际地质大会, 为何依然只留下了仪 式性的记号, 并没有真正在国际地质学界发出中国学者的声音。

\section{3 多伦多第 12 届国际地质大会上的中国代表团}

1913 年 8 月 7 日至 14 日,在加拿大多伦多召开第 12 届国际地质大会。根据《中国 地质学会史 $(1922 \sim 1981) 》$ 一书记载, 我国曾派广州矿业工程师 Parkin Wong 参加 ${ }^{[1]}$, 国 内地质史研究者一般均沿用这一说法。

虽然 1913 年 7 月 21 日《国际地质大会会员手册》上,并没有 Parkin Wong 的登记信 
息 ${ }^{[25]}$, 但作为中华民国的官方代表,Parkin Wong 最终确实出席了会议。《国际地质大会 第十二届会议记录》中记载, “大会主席宣布中华民国代表 Parkin Wong 先生到会, 并提议 将其列人大会主席团并担任副主席,提议通过。”(1) [ [26],84 页)大会记录中,Parkin Wong 登记的信息为“WONG,PARKIN, 广东,地址为美国纽约州倚色佳国际协会, 中华民国政府 代表” (2)。( [26],45 页) 国内地质史学界一直误以为 Parkin Wong 来自广州, 沈德容则指 出,1913 年他是从美国纽约市附近的小镇伊萨卡前往多伦多参会的。( [19],247 页) 然 而学界始终没有弄清楚这位中国官方代表的身份。

笔者通过对这段时间中国赴美留学生记录的查找,发现在 1908 年 8 月旧金山中西日 报社编印的《西美留学报告》中, 收录当时在美国西岸地区大学及专门学校的中国学生名 录,其中出现了 Parkin Wong 的名字,对应中文名为“黄伯芹”,祖籍广东新宁(3。黄伯芹当 时应是刚抵美不久,名单录人《西美留学报告》中“补遗及未详者”部分(4)(图 1)。

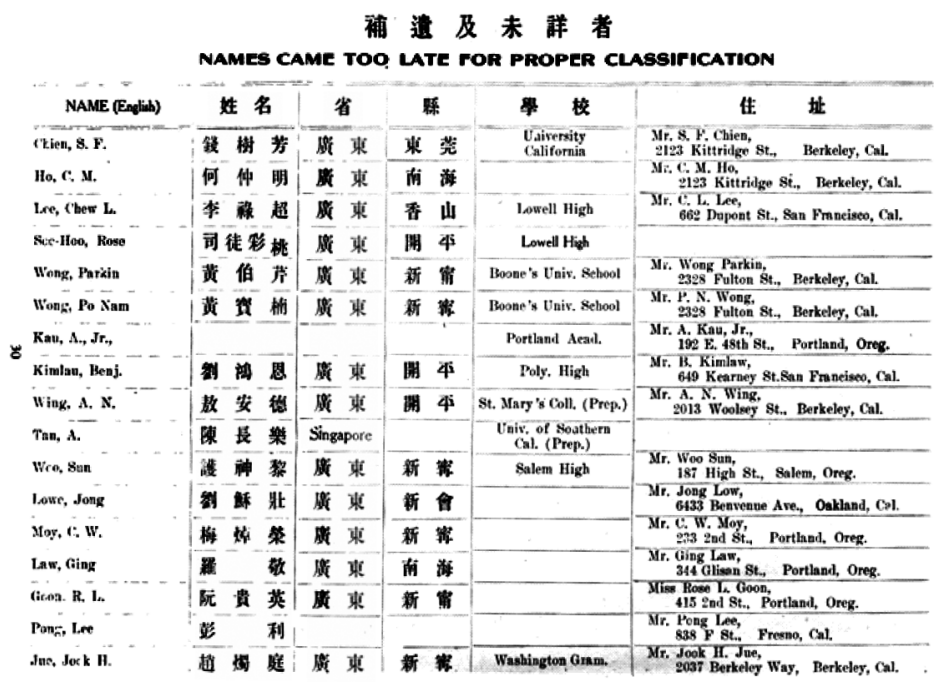

图 1 留美学员名录之“补遗及未详者”(《西美留学报告》,旧金山: 中西日报社印,1908 年,第 30 页)

根据笔者对黄伯芹后来学习生活的追查, 发现 1909 年黄伯芹人学康奈尔大学就读文 科 ${ }^{[27]}, 1913$ 年 2 月 5 日获得文科学士 (Bachelor of Arts)。获得学士学位之前,黄伯芹已经 完成学校本科学习要求, 于 1912 年开始硕士阶段的学习, 主修经济地质学及地层地质学 (Economic Geology \& Stratigraphic Geology), 导师为 Harris Ries 教授。 ${ }^{[28]}$ 黄伯芹在康奈尔 大学期间, 官方记录一直使用英文名 Parkin Wong, 但私下在华人学生群中依然使用中文

(1) 原文为: “Le président annonce que le délégué de la République Chinoise, M. Parkin Wong, est arrivé et propose qu'il soit ajouté au Bureau comme Vice-président pour la Chine. Approuvé. ”

(2) 原文为: “WONG, PARKIN, Canton, c/o Cosmopolitan Club, Ithaca, New York, U. S. A. 一Délégué du Gouvernement de la République de Chine”。

(3) 广东台山旧称新宁,辛亥之后改称台山。

(4) 和黄伯芹登记住址及就读学校相同的,还有同样来自广东新宁的黄宝楠。据查, 黄宝楠后于 1909 年进人密 歇根矿业学院( the Michigan College of Mines) 就读。详见 New Students at the Michigan College of Mines. The Calumet News. Saturday, Oct, 16, 1909. 2. 
名, 与赵元任等人相交甚好 (1)。另外, Harris Ries 教授也出席了 1913 年 8 月在加拿大多伦 多举办的第 12 届国际地质大会, 黄伯芹很有可能随同导师前往赴会, 因此,笔者推测黄伯 芹应该就是代表中国参加第 12 届国际地质大会的代表。1912 1913 年间, 北洋政府内 阁人员变换频密,何以委派黄伯芹代表中国出席第 12 届国际地质大会, 暂时无从考证, 但 从所学专业来看,黄伯芹也可算是一位比较合适的人选。

除黄伯芹之外,参加第 12 届国际地质大会并列人中国代表团名单中的还有 4 人, 分 别为在上海工作的加拿大矿务工程师 Wallace Broad, 来自 “直隶临城煤矿” ( Mines de Lincheng) 的总工程师 Kwong Yuan Kwang (中文名 “广荣光”) 和比利时矿务工程师 Oscar Mamet, 以及当时在美国哥伦比亚大学读书的 Wang Y. Tsenshan (中文名 “王臻善”)。两 位外国地质学家因为工作关系, 在中国代表团下签名, 而广荣光和王榛善都是中国人,均 有在美国学习地质的相关背景。

广荣光 1863 年出生于广东新宁, 是 1872 年第一批留美幼童, 1880 年从中学 ( Northampton High School) 毕业后,进人拉法叶学院 (Lafayette College) 主修土木工程, 接 触地质学、矿物学知识。1881 年曾被召回国, 并派往唐山开平矿务学堂继续学习矿务工 程。1885 年完成学业后曾计划赴英或回拉法叶学院继续学习,但始终没有成行。 ${ }^{\left[{ }^{[29]}\right.} 1897$ 年, 广荣光在开平矿务局担任总勘矿师, 先后任招远、平度、宁海等处金矿会办, 1905 1927 年期间,担任直隶省临城煤矿总工程师, 1906 年任直隶省矿政调查局总勘矿师。 ${ }^{[30]}$ 广荣光通过实地踏勘, 研究岩石和构造, 获得大量直隶省地质状况的第一手资料, 绘制 《直隶地质图》、《直隶矿产图》、《直隶石层古迹》, 分别发表在 1910 年《地学杂志》第 $1 、 2$ 和 3 4 号上。广荣光的这 3 幅地质制图, “反映出广荣光已掌握了现代地质学原理, 并能 结合中国的地质实践,这三项成果, 交相辉映, 开创了中国地质学家从事地质调查与研究 的先河”。 ${ }^{[31]} 1913$ 年参加多伦多地质大会的时候, 广荣光已经是一名在国内外享有声誉 的地质矿物学家。

王瑧善 1910 年从芝加哥大学获得化学治金学理学学士, 1912 年从哥伦比亚大学取 得法学硕士学位, 并继续攻读冶金学 (Metallurgy) 兼化学 (Chemistry) 博士学位。 ${ }^{[32]}$ 据查, 王臻善在哥伦比亚大学读书期间,曾在 1912 年和 1913 年先后两次得到政府批准(总统行 政令 1508 号及 1787 号) 加人美国地质科考队担任野外考察助理。 ${ }^{[33]}$ 根据《美国公务员委 员会年度报告》的记录, “应中国公使张荫棠的要求, 同时也根据地理考察中与别国科学 家保持友好合作的惯例, 任命王臻善先生担任地理考察的助理, 从 1913 年 7 月 1 日开始, 为期三个月。” ${ }^{[34]}$ 从第 12 届国际地质大会的召开时间看,王勲善出席这次大会, 恰是他担 任美国地理考察助理的时间。

与 1906 年在墨西哥城举办的第 10 届国际地质大会、1910 年在瑞典举办的第 11 届国 际地质大会相比,1913 年在加拿大多伦多举办的第 12 届国际地质大会上的中国代表不

(1) 胡适日记中数次提及黄伯芹。其中,民国三年(1914 年)九月二十五日,记送黄伯芹回国, 附有“海外送归人 图 (图略), 曾广智君摄, 并记: “归者为黄伯芹君。伯芹为此间同学之佼佼者。其人有热诚, 肯任事, 而明达 事理。所习为地学, 去年得为 Sigma Xi 会会员。留学之广东学生每每自成一党, 不与他处人来往, 最是恶习, 伯芹独不尔尔,故人多归之。”胡适:《胡适留学日记》,海南出版社 1994 年版,第 255 页。 
但人数更多,而且显然更为专业。尽管中国地质研究依然还在萌芽、探索的阶段,但从广 荣光、王臻善、黄伯芹的身上, 可以看出中国留洋学生正前赴后继、尽其所能开展地质矿冶 领域的奠基性工作,并积极参与了国际学术界的对话与交流。

\section{4 地质话语权力与国族身份}

近代中国, 地质学在国家积贫积弱、内忧外患的背景下初创发展起来,走过一段相当 艰难的路。20 世纪初举办的这几次国际地质大会,一方面是世界各国地质学者考证环球 地理之学的学术盛会, 实质上也是西方列强查勘全球矿产、清点资源咜备的一次良机。 1910 年第 11 届地质大会、1913 年第 12 届地质大会分别向各国征集煤铁矿产调查情况, 会后出版了两卷本《全球铁矿志》( The Iron Ore Resources of the World) 及三卷本《全球煤矿 志》(Coal Resources of the World)。为世界范围内的资源进行编目和绘图,一方面体现出 地质学科国际化的发展趋势, 另一方面无疑也向凯觎别国资源的资本主义强国提供了掠 夺的参考图谱。中国虽然派员参加了这两次会议,但就话语权力而言, 则是完全缺失的。

根据第 11 届地质大会记录,来自中国北洋大学的矿冶教授李特(Thomas T. Read)对 中国矿产情况做了报告。此次会后, 瑞典驻华公使致清政府外务部照会, “奉政府命令, 谨将《环球产铁源流》附地图一件备文照送”, 并呈上会议书记通告, 讲明书中 “有中国产 铁矿脉报告, 系天津之北洋大学教习笃玛司赖德君所著《论中国矿质源流》, 极为明晰”, 并附法语原件参会发言通告。该通告为邀请函模板, 由大会主席安特生( Johan Gunnar Andersson, 1874 1960) 签署, 填写发言人的姓名和背景。在清廷档案记录中(图 2), 这份 通告填写了发言人为 “来自中国天津北洋大学的 Thomas T. Read 教授”, 但另有一处改 动,将原文中“介绍自己祖国的自然资源” (ressources naturelles de sa patrie) 中的“祖国” ( sa patrie)二字以黑线划去, 改为了“中国” (le chine)。 ${ }^{[35]}$

从这一处细微改动, 可见当时大多数国家的资源情况是由本国地质学家来报告的,而 中国当时只能依靠在华工作的外国专家替中国发言。中国参会官方代表金大敏,虽主修 矿务, 但很可能从未在中国有任何实地考察与矿产勘探的经历, 在此次会议上完全没有任 何能力代表中国发言。

中国缺乏地质科学家的情况,在 1913 年第 12 届地质大会上已经有所改善。这次参 会的中国代表团中不乏专业人士, 尤其当时担任临城煤矿总工程师的广荣光, 在国内外均 有一定的知名度, 早在 1887 年就曾发表过关于中国北部煤矿开采的英文论文, ${ }^{[36]}$ 也曾代 表中国参加过 1910 年在德国举办的“国际矿物、冶金及应用地质学会议”。 ${ }^{[37]}$ 广荣光完全 有能力代表中国在煤炭资源的问题上发言, 然而此次会议上就中国煤炭资源进行报告的, 分别是美国阿肯色大学 (University of Arkansa) 的地质及矿务教授德瑞克 (Noah Fields Drake, 1864 1945) 以及日本地质调查所长井上禧之助 ( Kinosuke Inouye, 1873 1947)。 德瑞克概述了中国每个省份的煤炭资源分布情况, 并列出当时中国各大产煤公司, 其中日 本在抚顺, 英国在开平经营的煤矿产量高居榜首, 比中国自行开发的煤矿产量高出数倍之 多。井上禧之助用详细数据陈述了中国各大煤田的储量及开发情况, 还绘制了大量地图, 整理了各处煤矿的水份、挥发份、硫份、热质等技术参数。 ${ }^{[38]}$ 颇具争议的是, 井上禧之助还 


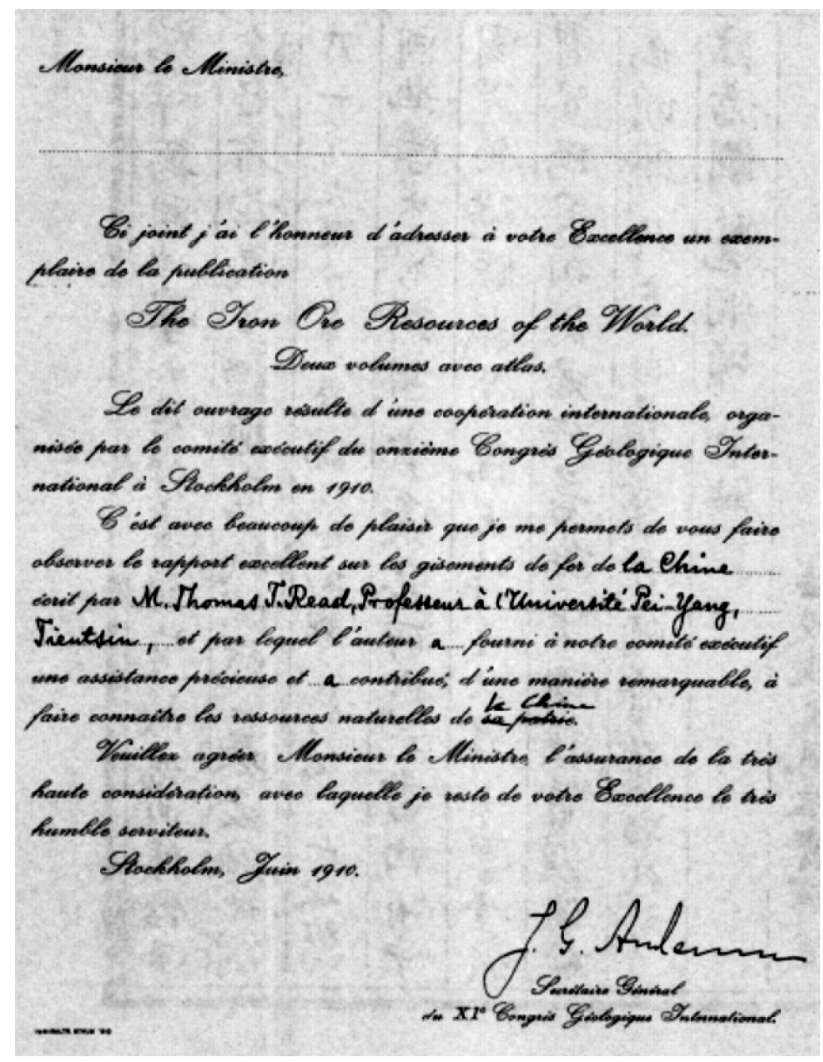

图 2 第 11 届地质大会 Thomas T. Read 参会邀请函

根据南满洲铁道株式会社的资料另外提交了长达 40 页的《满洲煤炭资源》报告, 全篇完 全没有提及“中国”。 ${ }^{[39]} 1906$ 年日俄战争之后, 日本和俄国签订《朴茨茅斯条约》,继承了 俄国在中国的矿业权。1909 年 9 月 4 日,清政府与日本政府签订了《东三省交涉五案条 款》, 承认日本国政府开采抚顺、烟台两处煤矿之权。 ${ }^{[40]}$ 虽然《大清矿务章程》明确规定洋 商在中国只有采矿权而无土地权,但井上禧之助在国际地质大会上堂而皇之将 “满洲” 与 “中国” 分置并代言的做法, 暗示着晚清政府矿业权丧失的背后, 实质上已无力阻止国家 主权被侵蚀之悲剧。

20 世纪初的这几次国际地质大会上中国代表话语权力的缺失,其原因之一在于近代 中国地质学发展起步较晚, 相关研究机制尚未出现, 职业科学家人数有限。中国自古以农 立国,对于矿产、土壤、石材的经验性地质知识积累历史悠久。章鸿到指出，《禹贡》中对 于土壤和矿产的记载、《山海经》中提到的各种石谱, 乃至《诗经》、《庄子》、《朱子语录》中 对地质沧桑变迁的思考, 都可被视为 “地质学萌芽时代应有的观念”。 ${ }^{[41]}$ 然而对于地质学 的根本问题, 古代中国学者并没有追踪研究, 因此这些萌生的观念并未得到充分的生长和 发展。相比之下, 西方近代地质学的发展更为成熟。西方地质学知识传人近代中国, 最初 主要通过传教士所办的报纸期刊,如英国传教士麦都思主编的《遐迩贯珍》、伟烈亚力主 编的《六合丛谈》、美国传教士《中西闻见录》等。 ${ }^{[42]}$ 洋务运动大举实业救国之后, 各种工 业发展所需的能源矿产成为燃眉之急, 在实用和求富的原则下, 矿业和地质学知识的译介 
得到重视。江南制造总局于 1873 年翻译出版了英国著名地质学家赖尔的《地学浅释》, 对近代中国地质学发展起到了启蒙的作用。 ${ }^{[43]}$ 但总体而言, 19 世纪末 20 世纪初, 中国地 质学发展尚处于萌芽阶段, 实际的勘探调查工作几乎空白,在很大程度上还要依靠外国专 家 (即“客卿”) 的帮助。即便中国学者自己也曾坦诚, “以二十世纪之初为止, 在此期内, 我国尚无地质学史可言”。[44]

中国代表当时在国际地质学界难以发声, 除了因为学科发展确实落后于世界, 另外还 有更深层的原因不容忽视。地质学研究与领土勘测、资源勘探、矿业生产, 乃至军事战略 等国家主权活动关系密切, 近代中国内忧外患频仍, 国运坎坷多多, 地质学研究的话语权 力也与国族地位身份有相当重大的关联。从学科本身的性质来看, 地质学是一门天然地 超越国家边界的、国际性的学科,中国地质学奠基人章鸿钊先生曾冷静地指出地质学研究 从学理上看是不分国籍疆界的:

研究地质是以地球为对象的, 就是认定地球是整个的。地球上无论何处, 可以互 相参照,还可以触类旁通借彼定此的; 所以地球上只要有一块土地尚未经过地质调 查, 他们便会不惮险阻, 款关进来, 代执调查的工作。在一方面看, 可以说他们越组代 席,在另一方面也可以说这位地主人是自己放弃义务的。( [45],81 页)

从这个角度来看, Thomas T. Read 对中国的铁矿资源报告、Noah Drake 以及井上禧之 助对中国乃至 “满洲” 煤炭资源的报告, 几乎是无可厚非的。他们在报告中, 都提到中国 的丰富资源并未引起足够关注，也未得到充分了解与合理开发。 ${ }^{[46]}$ 在 1913 年国际地质大 会上, 来自加拿大的专家极其尖锐地指出, 在世界地质图谱上, 中国 18 个省份都还是空 白，“没有任何官方机构在那里进行考察”,因此应该“委托给对远东足够熟悉的有能力的 地质学家, 对相关数据进行分析对比”。 ${ }^{[47]}$ 这种从学理上看似完全合理的建议, 后果和影 响却绝不限于地质学本身。国外地质学家在中国的科考活动, 历史上往往都会成为这些 国家殖民拓张的先期工作。例如, 德国地质学家李希霍芬 (Ferdinand von Richthofen, 1833 ～1905) 于 $1868 \sim 1872$ 年在中国进行了长达 4 年的地质、地理考察, 后写成五卷本巨著 《中国——亲身旅行和据此所作的研究成果》(China, Ergebnisse eigner Reisen und darauf gegründeter Studien, 简称《中国》)。他的考察和研究给中国带来了近代地学思想和方法, 翁文影曾叹服 “李氏于数年之间而造成中国地质学之主要纲领”, 并坦承 “李氏之成就, 而 节省吾人十年之工作时间” ${ }^{[48]}$, 但李希霍芬对于中国矿产及海港形势的考察, 直接引发了 德国对胶州的凯觎之心。对此, 鲁迅曾一针见血地指出: “冊曰一文弱之地质家, 而眼光 足迹间,实涵有无量刚劲善战之军队”, “盖自利 (李) 氏游历以来, 胶州早已非我有 矣”。[49]

正是充分理解了地质学研究和国族身份之间的关系, 章鸿钊在冷静的学理分析之外, 对近代中国在地质学方面的落后感到异常痛心疾首:

予尔时第知外人之调查中国地质者大有人在，顾未闻国人有注意及此者，夫以 国人之众, 竟无一人焉得详神州一块土之地质, 一任外人之深入吾腹地而不之知 也，已可耻矣! ${ }^{[50]}$

民国元年, 章鸿㻇写出《中华地质调查私议》, “痛陈中国调查地质之重要, 并建议着 手之计画, 以备在鼎革之初, 随着新兴的国运即开始工作”。章鸿钊对地质学的理解, 与 
洋务运动以实利为主的出发点有根本区别。他明确指出 “调查地质有学理与实用二途”, 从学理角度强调中国地质研究对于东亚地质学发展极为关键, 因此“我炎黄华旮至不能 以数千年生息饮豚之土地自开发而㦒明之,则群将些我为世界文明之污辱, 而欲免东大陆 不肖子之称也难矣”, 并进而强调, 即便地质调查结果并无实利, “而吾犹必以贡献真理为 地主应尽之谊”。( [45],87 页) 1912 年 1 月,南京临时政府就开始设立实业部矿物司地 质科,由章鸿涂担任科长,中国出现了以“地质”命名的机构实体。此后中央地质调查所、 地质研究所相继成立, 地质研究与教育同时并进, 中国地质学走上科学化、体制化发展的 道路。

第一次世界大战结束后, 1922 年第 13 届国际地质大会在比利时召开之时, 中国地质 学发展已经初见成效。除了作为中国代表出席大会的农商部合事、地质调查所会办 (副 所长)、代理所长翁文激之外, 中国地质学家章鸿钊、丁文江, 以及当时中央地质调查所聘 请的瑞典专家安特生、美国专家葛利普 (Amadeus William Grabau, 1870 1946) 都作为中 国代表团成员参会。中国代表团此次提交参会论文 4 篇, 分别为翁文濒与葛利普合著 《中国石炭纪》、丁文江所著《云南地质构造》、翁文激所著《中国某些地质构造对地震之影 响》和安特生所著《华北之新生代地层》。( [3],84 85 页) 这 4 篇论文均以中国地质构 造或变迁为题,并非对矿产资源的汇报, 从一个侧面说明中国地质学科从此已经从洋务派 对采矿实务的关注, 发展到一个学理探讨并重的阶段。中国地质学的成熟, 也使得此前西 方列强一度以地质勘探考察的名义, 凯颌中国资源的做法很难再行得通了。从这个意义 上, 中国地质学科的建立, 可被视为民族国家自保的一种科学手段。值得一提的是, 此次 大会将参会的南满洲铁道株式会社首席地质学家村上铅藏 (Hanzo Murakami) 的研究列于 中国名下,而不再按照 1913 年多伦多会议的做法, 将“满洲”单列出来。对此, 沈德容评 论说: “中国政府无法阻止日本人侵东北各省, 但是地质学界却已经决定, 要将地质发现 各归其位”。( [19],250 页) 由此可见,科学话语界定国家疆界、维护民族身份之力, 不容 小虡。

\section{5 结 语}

本文以 20 世纪初三次国际地质大会作为观察近代中国地质学科初创时期发展变迁 的窗口, 通过一手史料考证中国派员及参会的情况, 钩沉被湮没和遗忘的第一代中国地质 学人资料, 并从这几次国际地质大会中国代表沉默的历史中, 反思科学话语权力与国族身 份之关联。1906 年, 中国拟派外交官员参加在墨西哥城举办的第 10 届国际地质大会, 将 其作为一次外交事件而非学术会议, 反映出近代中国初涉国际学术交流的滥尤。1 1910 年, 在瑞典举办的第 11 届国际地质大会, 从中国派出的同文馆留德学员金大敏身上,可以 看出晚清末年洋务学堂从实用主义、功利主义的角度来推动新式教育的努力, 但这种努力 在当时的现实政治和官僚体制中并未受到应有的重视。1913 年,多伦多第 12 届国际地 质大会上的中国代表背景不一,但都是较早投身于矿冶和地质研究的优秀的中国学人。 户荣光为第一批留美幼童, 从开平矿务学堂学成之后, 成为中国第一代地质学家; 黄伯芹 自费从香港前往美国,刚刚开始矿物地质专业的硕士学业; 王榛善已经开始攻读地质学博 
土学位,正参与美国科学家的实地科考。值得一提的是,这些与会代表后来均为中国近代 科学发展做出了各自的贡献。除了学界非常熟悉的中国地质学先驱邚荣光之外, 就笔者 能够查证的资料,参加第 11 届国际地质大会的金大敏后于 1921 年 1 月 28 日被任命为北 洋政府农商部“技正”。 ${ }^{[51]}$ 参加第 12 届国际地质大会的黄伯芹在康奈尔大学非常活跃, 曾 是康奈尔科学荣誉学会 $\left(\right.$ Sigma Xi) 的成员, 提交过有关中国地质学研究的论文 ${ }^{[52]}$,并在 中国科学社的筹办中发挥过重要作用 ${ }^{[53]}$ 。王榛善 1916 年学成回国, 1916 至 1923 年期 间,在第一届北洋政府农商部应用地质科担任矿业技师 ${ }^{[54]}$,负责调查了山东牟平莱山、招 远玲珑、平度旧店金矿地质及开采情况 ${ }^{[55]}$ 。

当年,这些代表中国参加国际地质大会的留洋学子和地质工作者们由于各种历史原 因,并没有在大会上留下如 1922 年翁文影那般让世界地质学界刮目相看的表现,但他们 作为第一代中国地质学人,在国际学术会议上的亮相本身,是中国地质学正在萌芽和发展 的最好证词,而他们䇤路蓝缕以启山林的努力,不应该被历史遗忘。

\section{参 考 文 献}

1 夏湘蓉, 王根元. 中国地质学会史 $(1922 \sim 1981)[$ M ]. 北京: 地质出版社, 1982.

2 郭金彬. 中国科学百年风云: 中国近现代科学思想史论 $[M]$. 福州 : 福建教育出版社, 1991 .

3 李学通. 中国学者首次参加国际地质大会经过及影响 $[\mathrm{J}]$. 科学文化评论, 2018, 15(2): 80 90.

4 丁文江. 丁文江文集 [C].第 1 卷. 长沙: 湖南教育出版社, 2008. 20.

5 李学通. 书生从政(翁文影) [ M ]. 兰州: 兰州大学出版社, 1996. 69 .

6 宋广波. 丁文江年谱 $[\mathrm{M}]$. 哈尔滨: 黑龙江教育出版社, 2009. 59.

7 外务部致墨西哥驻华代使阿拉达米拉依那秀照会 $[G] / /$ 李国荣. 晚清国际会议档案. 第 5 卷. 扬州: 广陵书社, 2008. 2747.

8 墨西哥驻华署使胡尔达致庆亲王奕劻照会 $[\mathrm{G}] / /$ 李国荣. 晚清国际会议档案. 第 5 卷. 扬州: 广陵书社, 2008. 2751 .

9 外务部致兼使墨西哥大臣梁诚咨文 $[\mathrm{G}] / /$ 李国荣. 晚清国际会议档案. 第 5 卷. 扬州: 广陵书社, 2008. 2758 $\sim 2759$.

10 兼使墨西哥大臣梁诚致外务部咨呈 $[\mathrm{G}] / /$ 李国荣. 晚清国际会议档案. 第 5 卷. 扬州: 广陵书社, 2008. 2765 $\sim 2769$.

11 李春辉. 近代拉丁美洲的华工问题 $[J]$. 近代史研究, 1981,(4)：166 167.

12 Boletín oficial de la Secretaría de relaciones exteriores, Volume 21 [G]. Secretaría de Relaciones Exteriores, Mexico. 1905. 207.

13 Appointment of a Chinese Minister [ R ] // Congressional Series of United States Public Documents. Volume 4694, 1904. 94.

14 赵尔巽. 清史稿 $[M]$. 第 16 册. 卷 160 . 北京: 中华书局, 1977. 469.

15 Martínez M, Felipe L, Riart O P. The 20th International Geology Congress, México 1956[J]. Episodes. 2009, (32. 3) : $194 \sim 207$.

16 瑞典驻华公使倭伦白致外务部信函 $[G] / /$ 李国荣. 晚清国际会议档案. 第 5 卷. 扬州: 广陵书社, 2008. 5651 $\sim 5652$.

17 Compte rendu de la XI: e session du Congrès géologique international (Stockholm 1910) [ G]. Kungl boktryckeriet, P. A. Norstedt \& söner, 1912. 20, 80.

18 韩琦. 从矿务顾问、化石采集者到考古学家: 安特生在中国的科学活动 $[\mathrm{C}] / /$ 法国汉学. 第 18 辑. 北京: 中华书 
局, 2018. 30.

19 Shen G Y. Going with the Flow: Chinese Geology, International Scientific Meetings and Knowledge Circulation[C]// The Circulation of Knowledge Between Britain, India and China. Brill, 2013.

20 徐健. 晚清官派留德学生研究 $[\mathrm{J}]$. 史学集刊, 2010,(1): $72 \sim 79$.

21 苏精. 清季同文馆及其师生 $[M]$. 上海：上海印刷厂(自印本)，1985. 235.

22 恭亲王, 等. 奏设同文馆折 (附章程) [ $\mathrm{G}] / /$ 舒新城. 中国近代教育史料. 上册. 北京: 人民教育出版社, 1961. 118.

23 Chronik der Königlichen Friedrich-Wilhelms-Universität zu Berlin für das Rechnungsjahr [ G]. Humboldt-Universität zu Berlin. 1903. 75 .

24 Sundquist B, Christer N. Science and Honour: The 11th International Geological Congress in Stockholm 1910[J]. Episodes-Newsmagazine of the International Union of Geological Sciences, 2004, (27. 4 ) : 287.

25 Members-( July 21) International Geological Congress (12th, 1913: Toronto, Ont. ) [ DB/OL] . (2019-04-20) [201904-30]. https: //archive. org/details/membersjuly21 num00inteuoft

26 Congrès Géologique International, Compte-Rendu de la XII Session, Canada[G]. Ottawa: Government Printers, 1913.

27 The University Records $[$ G]. Ithaca: Cornell University, 1910. 746.

28 Catalogue No. 1912-13 [G]// Official Publications of Cornell University, Volume IV, No. 16, Ithaca: Cornell University, 1913, 111.

29 A Student in China[J]. The Lafayette Weekly, 1884, (10-11): 54.

30 "Kwong Young Kong", Chinese Educational Mission Connections(1872-1881) [ DB/OL]. (2019-04-20) [2019-04-30] . http: //www. cemconnections. org/index. php? option = com_content\&task = view\&id $=$ 92\#FN1 1

31 吴凤鸣. 中国早期区域地质矿产调查、人物、成果及其历史和影响 $[\mathrm{C}] / /$ 中国地质学会地质学史专业委员会第 20 届学术年会论文汇编. 北京: 中国地质学会地质学史研究会, 2008. 47-68.

32 Catalogue and General Announcement, 1913-1914[G]. New York: Columbia University, 1914. 317.

33 Presidential executive orders, numbered 1-8030, 1862-1938[G]//The List, Volume 1. New York: Archives publishing company, 1944. 148, 170.

34 Annual Report $[\mathrm{R}]$. United States Civil Service Commission, 1914. 128.

35 瑞典驻华公使倭伦白致外务部照会 $[\mathrm{G}] / /$ 李国荣. 晚清国际会议档案. 第 10 卷. 扬州: 广陵书社, 2008. 5653 5656.

36 Kwong Y. K. Coal Mining in North China[J]. The Engineering and Mining Journal (New York), 1887, (XLIV): 220, 221, 238.

37 Internationaler Kongress fiur Bergbau, Hüttenwesen, Angewandte Mechanik und Praktische Geologie: Mitgliederliste und Allgemeines [G]. Selbstverl: des Arbeitsausschusses des Kongresses, 1910. 153

38 Inouye K. The Coal Resources of China $[\mathrm{R}] / /$ The coal resources of the world [microform]: an inquiry made upon the initiative of the Executive Committee of the XII International Geological Congress, Canada, 1913. 169 237.

39 Inouye $\mathrm{K}$. The Coal Resources of Manchuria [ $\mathrm{R}$ ]// The coal resources of the world [microform]: an inquiry made upon the initiative of the Executive Committee of the XII International Geological Songress, Canada, 1913. 238 278.

40 王铁崖. 中外旧约章汇编 $[\mathrm{G}]$. 第 2 册. 北京: 三联书店, 1957. 599.

41 章鸿钊. 中国研究地质学之历史 $[\mathrm{J}]$. 中国地质学会志, 1922, (Z1) : 27.

42 周其厚. 论晚清西方地质学的输人及影响 $[\mathrm{J}]$. 齐鲁学刊, 2003,(2) : 21.

43 吴凤鸣. 明清两代几本地质译著简评 $[\mathrm{J}]$. 自然辩证法研究, 1985, (4) : 68 .

44 叶良辅. 地质学小史 $[\mathrm{M}] / /$ 中国地质学史二种. 上海: 上海世纪出版社, 2011. 71.

45 章鸿钊. 中国地质学发展小史 $[\mathrm{M}] / /$ 中国地质学史二种. 上海: 上海世纪出版社, 2011. 81 .

46 China $[\mathrm{R}] / /$ The Iron Ore Resources of the World: An Inquiry Made Upon the Initiative of the Executive Committee of the XI International Geological Congress, Stockholm, 1910,(2): $48 \sim 49$.

47 De Margerie $\mathrm{E}$. The Geological Map of the World $[\mathrm{R}] / /$ Compte-rendu de la XIIe session du Congrès géologique internation- 
al, Canada, 1913, 185.

48 Wong W H. Richthofen and geological work in China $[\mathrm{J}]$. Bulletin of the Geological Society of China, 1933, 12(12) : 312 .

49 鲁迅. 中国地质略论 $[M] / /$ 鲁迅全集. 第 8 卷. 北京: 人民文学出版社, 2005. 7.

50 章鸿到. 六六自述 $[\mathrm{M}]$. 武汉: 武汉地质学院出版社, 1987. 21.

51 农商部令第一八号 $[\mathrm{G}] / /$ 北洋政府公报. 第 170 卷. 上海：上海书店, 1921. 122.

52 Richtmyer F K, Hunt W F, Edward F. E. F. Chillman. Sigma Xi, The Scientific Research Honor Society[ J]. Sigma Xi Quarterly, 1914, 2(3): $72 \sim 83$.

53 张剑. 中国科学社股东、股金与改组 $[\mathrm{J}]$. 中国科技史料, 2003, 24(2) : 95 103 .

54 Jan F B. Collected Writings of Flora Belle Jan $[\mathrm{M}]$. Xlibris Corporation, 2008. 230.

55 山东省地方史志编纂委员会. 山东省志: 地质矿产志 $[G]$. 济南: 山东人民出版社, 2010. 274.

\title{
A History of China's Early Participation in International Geological Conferences: Reflections on the Relationship between Scientific Discourse and National Identity
}

\author{
WANG Xiulu \\ (Sun Yat-sen University, Guangzhou 510275, China)
}

\begin{abstract}
Initially organized by European geologists at the end of the 19th century, the International Geological Congress is now the largest and most influential academic gathering in the field of geological studies. Records of China's participation in the Congress date back to the 10th International Geological Congress in Mexico City held in September 1906. Subsequently, China sent official delegates to the 11th International Geological Congress in Stockholm in 1910, and the 12th International Geological Congress in Toronto in 1913. Based on relevant historical and archival materials, this paper provides a historical review of China's early participation in the International Geological Congress, focusing on the attending delegates, whose identities have remained largely unknown to this day. Taking the International Geological Congress as a window, this paper examines the history of the development of geology in China in the early 20th century, and reflects on the relationship between scientific discourse and the construction of national identity in China at a time when the country was under the dual pressure of foreign invasion and internal turmoil.
\end{abstract}

Keywords International Geological Congress, scientific discourse, national identity 